\title{
La carta pastoral "Justo Salario": el intento de Mons. Thiel por iniciar la Doctrina Social de la Iglesia católica en Costa Rica (1893)*
}

\section{Resumen}

Este artículo explica cuáles fueron los motivos reales y las repercusiones políticas que tuvo la publicación de la trigésima carta pastoral del segundo obispo de Costa Rica, Bernardo Augusto Thiel, en 1893. Esto se logró mediante el análisis cualitativo de los documentos analizados, como fueron la carta pastoral "Justo Salario", la Rerum Novarum, las respuestas que dio el gobierno civil a la carta pastoral, así como los ataques en los periódicos y las explicaciones que dio el obispo sobre su escrito. Como resultado se observó que la publicación fue más que una simple "tropicalización” de la encíclica de León XIII de 1891, la Rerum Novarum. Fue una tentativa por parte de Mons. Thiel para incorporar la Doctrina Social de la Iglesia católica en Costa Rica, acto llevado a cabo en medio de las elecciones presidenciales de 1893-1894, en las cuales participaba un partido católico. El trabajo permitió concluir que las autoridades civiles no estaban dispuestas a aceptar este tipo de participación de la clerecía por considerarla un ataque al orden social existente, por ello la atacó con diferentes formas y medios.

\section{Palabras clave}

Tesauro: pobreza, liberalismo, política, elecciones.

Autor: Iglesia católica.

Referencia para citar este artículo: Schroeder Barrantes, Ana María y Sandí Morales, José Aurelio. "La carta pastoral "Justo Salario": el intento de Mons. Thiel por iniciar la Doctrina Social de la Iglesia católica en Costa Rica (1893)". Anuario de Historia Regional y de las Fronteras 23.2 (2018): 115-139. DOI:10.18273/revanu.v23n2-2018004

Ana María Schroeder Barrantes: magíster en Docencia Universitaria por la Universidad Continental de las Ciencias y las Artes, Costa Rica. Bachiller y magíster en Historia por la Universidad Nacional, Costa Rica. Profesora de Historia y Geografía en secundaria, así como profesora de Historia de la Iglesia católica en la Universidad Católica de Costa Rica. Código ORCID: https://orcid.org/0000-0003-0603-372X. Correo electrónico: anaschroba@gmail.com y anamaria.schroeder@weizmancr.net.

José Aurelio Sandí Morales: tesiario doctoral de la Scuola Normale Superiore di Pisa, Italia. Magíster y bachiller en Historia por la Universidad Nacional, Costa Rica. Su maestría es con énfasis en Poder y Control Social. Miembro investigador del Instituto de Investigaciones Histórica Mons. Bernardo Augusto Thiel. Profesor de Historia en la Escuela de Historia de la Universidad Nacional, sede Central. Código ORCID: https://orcid.org/0000-0002-5950-6626. Correo electrónico: jose.sandi.morales@una.cr y jasm77historia@gmail.com.

\footnotetext{
* Este artículo forma parte de la tesis doctoral de José Aurelio Sandí Morales titulada "La Santa Sede in Costa Rica 1870-1936. Il rapporto politico-religioso e diplomatico tra il governo del Costa Rica, la gerarchia cattolica del Paese e la Santa Sede nel periodo liberale costaricano". El artículo que presentamos es parte de un proyecto que vincula la tesis con el Instituto Arquideocesano de Investigaciones Históricas de San José, Costa Rica.
} 


\title{
The Pastoral Letter "Justo Salario": Monsignor Thiel's Attempt to Initiate the Catholic Church's Social Doctrine in Costa Rica (1893)
}

\begin{abstract}
This article explains the reasons and political repercussions of Bernardo Augusto Thiel's (second Costa Rican bishop) thirtieth pastoral letter publication, in 1893. This was concluded through a qualitative analysis of the "Justo Salario's" pastoral letter, the Rerum Novarum, the reactions of the civil government to the documents, the attacks from the newspapers and the explanations given by the bishop about his writing. As a result, it was observed that the document represented more than a simple "tropicalization" of Leon XIII's circular Rerum Novarum, published in 1891 since bishop Thiel used it to incorporate the Social Doctrine of the Catholic church in Costa Rica, which he did in the frame of the presidential election of 1893-1894, when a catholic party actively participated. This study concludes that civil authorities were not willing to accept the clergy's political representation and considered it a threat to the existing social order reacting against it using different means and methods.
\end{abstract}

Keywords

Thesaurus: Poverty, Liberalism, Politics, Elections.

Author's keywords: Catholic Church.

\section{A Carta Pastoral "Justo Salário": A Tentativa do Bispo Thiel de começar com a Doutrina Social da Igreja Católica na Costa Rica (1893)}

\section{Resumo}

Este artigo explica quais foram os verdadeiros motivos e as repercussões politicas da publicação da trigésima carta pastoral do segundo bispo de Costa Rica, Bernardo Augusto Thiel, em 1893. Para tanto, se procedeu à análise qualitativa de documentos como a carta "Justo Salario", a Rerum Novarum, as respostas dadas pelo governo civil ao documento, os ataques nos jornais e as explicações que deu o bispo sobre seu escrito. Como resultado se observou que a publicação foi mais do que uma simples "tropicalização" da encíclica de Leão XIII de 1891, a Rerum Novarum. Foi uma tentativa por parte de Dom Thiel de incorporar a Doutrina Social da Igreja Católica na Costa Rica. Ato que realizou em meio às eleições presidenciais de 1893-1894, das quais participou um partido católico. $O$ trabalho permitiu concluir que as autoridades civis não estavam dispostas a aceitar esse tipo de participação do clero por considerá-la um ataque à ordem social existente, contra o que resistiram de diferentes maneiras.

Palavras-chave

Thesaurus: pobreza, liberalismo, politica, eleições.

Palavras-chave do autor: Igreja católica. 


\section{Introducción}

La Rerum Novarum se convirtió en el inicio de la Doctrina Social de la Iglesia católica en el mundo. ${ }^{1}$ Aunque hay que aclarar que ni León XIII ni su cuerpo curial fueron los que acuñaron dicho concepto. Más bien, fue hasta Pio XII, y especialmente en el post Concilio Vaticano II, que la jerarquía católica comenzó a hablar de manera alternativa "de doctrina, magisterio o enseñanza social de la Iglesia". ${ }^{2}$ El documento leonino vio la luz como una respuesta a la realidad de los obreros en medio de las revoluciones industriales en el mundo occidental. Para muchos este documento fue la propuesta católica no solo contra la mísera situación de los obreros, sino también su ofrecimiento ante las ideas socialistas que nacieron en torno a los problemas de los trabajadores. El texto tuvo su origen no en una política propia de la Curia Romana, sino más bien en un conglomerado de grupos católicos de diferentes comunidades europeas que se preocuparon por la realidad de los obreros. ${ }^{3}$ De igual manera, el texto fue analizado, criticado ${ }^{4}$ y puesto en práctica en la mayoría del mundo católico y Costa Rica no fue la excepción.

La Rerum Novarum abordó temas variados La encíclica daba inicio con el motivo de su publicación este era "el cambio operado en las relaciones mutuas entre patronos y obreros"; a causa de "la acumulación de las riquezas en manos de unos pocos y la pobreza de la inmensa mayoría", ${ }^{5}$ hecho que se había convertido en el principal mal que aquejaba a los obreros. Además, atacó las propuestas socialistas, acusándolas de empeorar "la situación de todos los obreros, en cuanto tratan de transferir los bienes de los particulares a la comunidad", ya que este postulado eliminaba al obrero "la esperanza y de la facultad de aumentar los bienes familiares y de procurarse utilidades", ${ }^{6}$ lo cual generaría más odios y rencores entre todos los miembros de la sociedad.

Para corregir estos males, el Obispo de Roma proponía una solución católica. Dicha propuesta se centraba en el papel que deberían de jugar las asociaciones corporativas. El Papa planteó una acción tripartita, donde se llamaba a actuar a la Iglesia, al Estado y a las asociaciones obreras. La propuesta fue fundamental, ya que presentó una Iglesia que debía actuar y no solo hablar. También llamó al Estado a proceder como el

\footnotetext{
${ }^{1}$ Sabino Frigato, La difficle democracia. La dottrina sociale della Chiesa da Leone XIII a Pio XII (18781958) (Torino: Editrice EFETA, 2007) 9

${ }^{2}$ Fernando Moreno V., Iglesia, política y sociedad (Santiago: Ediciones Universidad Católica de Chile, 1988) 87.

${ }^{3}$ Para leer un texto sobre los diversos grupos católicos que analizaban la situación de los obreros a finales del siglo XIX, así como los efectos que podían tener las propuestas socialistas en la sociedad del periodo se recomienda: Marie-Dominique Chenu, La Dotrina Sociales della Chiesa, origine e sviluppo (1891-1971) (Brescia: Queriniana, 1982).

${ }^{4}$ Para observar el análisis propuesto por la izquierda sobre este documento, el cual lo catalogó como un texto sin mayor aporte e importancia se recomienda consultar: Picciaredda Stefano, "Protestanti e socialista alla prova dell'enciclica", en Stefano Picciaredda e Vittorio V. Alberti, Il mondo di Leone XIII. L'incontro della Chiesa con il XX secolo (Roma: Edizioni liberal, 2006) 87-95.

${ }^{5}$ León XIII, Rerum Novarum, http://w2.vatican.va/content/leo-xiii/es/encyclicals/documents/hf 1-xiii enc_15051891_rerum-novarum.html (17 de septiembre de 2017).

${ }^{6}$ León XIII, Rerum Novarum.
} 
principal defensor de la unión de los obreros para que estos lucharan por sus derechos. A los obreros y patronos les proponía actuar bajo los principios cristianos para llegar a establecer una paga justa.

León XIII solicitaba una participación de las autoridades civiles, bajo la premisa de defender el bien del obrero en los ámbitos moral y material. El Papa sostenía que el Estado debía de ser defensor "de los bienes corporales y externos" del obrero, lo cual se conseguiría si se cumplía el objetivo de "[...] librar a los pobres obreros de la crueldad de hombres codiciosos que, a fin de aumentar sus propias ganancias, abusan sin moderación alguna de las personas, como si no fueran personas sino cosas". ${ }^{7}$

La argumentación del Pontífice seguía proponiendo un trabajo en conjunto entre los diversos actores sociales. Para ello propuso un cambio de comportamiento a los patronos, así como una unión entre ellos y el Estado en sus posturas económicas. Para León XIII, “[...] los ricos y patronos: no debían considerar a los obreros como esclavos; respetar en ellos, como es justo, la dignidad de la persona, sobre todo ennoblecida por lo que se llama el carácter cristiano". Según el Pontífice, al Estado le correspondía velar por el bien de la mayoría, mediante la creación y cumplimiento de leyes civiles justas. Las cuales unidas a las leyes divinas velarían por la buena convivencia social. ${ }^{8}$

Dentro del cambio que pedía León XIII a los patronos, estaba el de procurar un salario justo como retribución por las horas trabajadas por los obreros. Según el Obispo de Roma los patronos debían de tener presente que "[...] para establecer la medida del salario con justicia hay que considerar muchas razones; pero, generalmente, tengan presente los ricos y los patronos que oprimir para su lucro a los necesitados y a los desvalidos y buscar su ganancia en la pobreza ajena no lo permiten ni las leyes divinas ni las humanas". 9 Además, el Papa exhortaba a mejorar el trato a los obreros. En especial para con las mujeres, los ancianos y los niños, a los cuales se les debía de reducir las horas y cargas de trabajo, por no tener las condiciones físicas de hombre adulto y robusto. Por último, llamaba a crear espacios de descanso laboral según el trabajo realizado, así como el descanso festivo, tanto para recuperar fuerzas como para el cumplimiento de los deberes religiosos de todos.

\section{La realidad socio-económica y política de Costa Rica en el año 1893}

En la Costa Rica de las últimas décadas del siglo XIX y la primera mitad del XX predominaron las ideas de corte liberal. Estas proponían que las intervenciones del Estado en la economía debían limitarse a asegurar el cumplimiento de las leyes, garantizar la seguridad nacional y llevar a buen puerto las relaciones exteriores.

\footnotetext{
${ }^{7}$ León XIII. Rerum Novarum.

${ }^{8}$ León XIII. Rerum Novarum.

${ }^{9}$ León XIII. Rerum Novarum.
} 
Ejemplo de ello fue: el estímulo dado a la siembra de café, ${ }^{10}$ pues, desde mediados de la década de 1820 y a través de concesión de tierras públicas y la exención de impuestos por el Estado se incentivó su siembra. ${ }^{11}$

La importancia económica de este cultivo generó una fuerte dependencia, lo cual, a lo largo del tiempo, provocó una serie de problemas económicos. En palabras de Carolyn Hall:

[...] la política "laissez-faire laissez-passer" que hasta la década de los años 30 había permitido el desarrollo de una economía en la cual predominaban solo dos productos primarios, fue gradualmente reemplazada por una creciente intervención estatal, tanto para buscar racionalización dentro de la anticuada industria cafetalera, como para considerar la diversificación de la economía nacional. ${ }^{12}$

Durante la década de 1870 se experimentó otra fase de crecimiento económico con la construcción del ferrocarril al Atlántico. Esta obra no solo permitió la salida de las exportaciones por una ruta más directa a Europa y al Este de los Estados Unidos, sino que también condujo al desarrollo de la actividad bananera. ${ }^{13}$ Con ello se integró la región caribeña a la economía nacional, con características muy diferentes a las que incorporó la producción de café en el Valle Central, pues el negocio del banano se desarrolló bajo una lógica del enclave.

Las consecuencias negativas heredadas de esta economía del siglo XIX fueron varias. La primera fue las complicaciones de un capitalismo absorbente, la segunda, la desviación antidemocrática de su organización social, la tercera, los bajos niveles de bienestar de la clase campesina, y la última, los insuficientes recursos fiscales del Estado para atender las necesidades sociales. ${ }^{14}$

Por otro lado, el deterioro de la situación monetaria interna se reflejó en la caída del cambio del peso respecto a las monedas con que se comerciaba. Esta desvalorización de la moneda durante la década de 1890 llevó a la decisión, por parte de Rafael Yglesias,

\footnotetext{
${ }^{10}$ El cultivo del café se estableció en Costa Rica en la primera mitad del siglo XIX. Fue desarrollado principalmente por agricultores descendientes de los colonizadores españoles. Este fruto sustituyó la siembra de alimentos básicos, especialmente en los asentamientos cercanos a la Meseta Central, pero se mantuvo a la vez la estructura agraria de consumo familiar. Para profundizar más sobre este tema, véase: Carolyn Hall, El café y el desarrollo histórico-geográfico de Costa Rica (San José: Editorial Costa Rica y Universidad Nacional, 1976) 15.

${ }^{11}$ José Antonio Salas, "La privatización de los baldíos nacionales en Costa Rica durante el siglo XIX: Legislación y procedimientos utilizados para su adjudicación”, Revista de Historia.15 (1987): 63-118.

${ }^{12}$ Hall 18.

${ }^{13}$ El banano es una planta que se ha cultivado en Costa Rica desde finales del siglo XIX en las regiones costeras del país en especial en el Caribe. Estas áreas se desarrollaron como enclaves que, por lo general, estaban asociados con el cultivo de productos de exportación en muchos países del tercer mundo. Para profundizar más sobre este tema, veáse: Jeffrey Casey, Limón: 1880-1940. Un estudio de la Industria bananera en Costa Rica (San José: Editorial Costa Rica, 1978).

${ }^{14}$ Jorge León, Historia económica de Costa Rica en el siglo XX: crecimiento de políticas económicas (San José: Editorial de la Universidad de Costa Rica, 2014) 25.
} 
de establecer el patrón oro en 1896, como referencia para la moneda nacional. La implementación de este nuevo sistema monetario se realizó paulatinamente entre 1896 y 1902, y coincidió tanto con la mejora del precio del café y con la continua y rápida ampliación de las exportaciones de banano, como con la crisis finisecular.

Por su parte, el Estado liberal costarricense logró establecer su régimen de "bienestar", (siempre bajo la consigna de orden y progreso) mediante la articulación entre la sociedad civil, las comunidades y las políticas públicas en materia de salud, vivienda, servicios sociales, políticas de empleo y orientación del gasto público hacia el gasto social. La pobreza, para el caso costarricense, puede entenderse como un proceso de construcción social permanente, llegando al extremo, dentro de la sociedad económica capitalista, de mercantilizarse como categoría y como realidad institucional. Esta situación hacía necesaria la pobreza como argumento legitimador para la existencia política y parasitaria de las clases políticamente dominantes, de su discurso ideológico y de su legitimación, e incluso, para los procesos de acumulación de capital. ${ }^{15}$

Dos de las principales vías de acción del Estado liberal costarricense para solucionar este problema social estuvieron enfocadas en la caridad y la beneficencia, especialmente impulsadas por organismos religiosos y laicos. La Iglesia por su parte, veía en la caridad y beneficencia la misma expresión y extensión política de su actuar, como una manifestación de una mejor distribución social de la riqueza. ${ }^{16} \mathrm{El}$ verdadero problema que representó la pobreza fue que puso en evidencia el fracaso del modelo oligárquico burgués, al no satisfacer las necesidades elementales del pueblo costarricense, y su incapacidad para establecer un sistema de acumulación de capital al servicio de los sectores populares. Este inconveniente se evidenció mediante la ausencia de planes o programas propuestos para atacar la pobreza, de ahí que el Estado optó por invisibilizar la magnitud del problema en vez de buscar posibles políticas para mitigarlo. De esta manera, más allá de destinar fondos para atacar este problema, se desarrollaron estrategias para contenerlo mediante la vinculación del Estado con las municipalidades, la caridad pública, la filantropía oligárquica y la beneficencia cristiana. ${ }^{17}$

Ahora bien, para el año de 1893 la vida política del país no era más tranquilizadora que la económica. Para aquel año gobernaba José Joaquín Rodríguez Zeledón, quien había triunfado en las elecciones de 1889. Dicha victoria se dio por varios factores, pero en particular por la ayuda brindada por los sacerdotes del país a su candidatura, los cuales colaboraron no solo en la campaña electoral, sino en evitar el fraude que el Gobierno pretendía realizar a favor de su candidato: Ascensión Esquivel Ibarra. Dicha unión entre los rodriguistas y el catolicismo debe ser entendida dentro del

\footnotetext{
${ }^{15}$ Vladimir De la Cruz, "Pobreza y lucha social en Costa Rica, 1870-1930", Pobreza e Historia en Costa Rica. Determinantes estructurales y representaciones sociales del siglo XVII a 1950, ed. Ronny Viales (San José: Editorial de la Universidad de Costa Rica, 2005) 55.

${ }^{16}$ De la Cruz, "Pobreza y lucha social en Costa Rica, 1870-1930" 61.

${ }^{17}$ Ronny Viales, "El régimen liberal de bienestar y la institucionalización de la pobreza en Costa Rica 18701930", Pobreza e Historia en Costa Rica. Determinantes estructurales y representaciones sociales del siglo XVII a 1950, ed. Ronny Viales, 93.
} 
marco de lo sucedido en el periodo 1882-1886 y en especial por las denominadas leyes "anticlericales" de $1884 .{ }^{18}$

La declaratoria de estas leyes generó un ambiente de tensión entre el poder civil y el eclesial. Ante ellas, el obispo Thiel buscó diferentes maneras para eliminarlas y lograr que lo "perdido" por los católicos durante los años 1884-1886, se recuperara. Su estrategia para conseguir tal objetivo lo llevó a involucrarse en la arena política. En un inicio lo llevó a cabo mediante el apoyo a José Joaquín Rodríguez (de manera muy discreta por su parte, pero muy abierta por parte del presbiterado) y luego, mediante la creación de un partido político. El origen del Partido Unión Católica se debió a que los católicos vieron que en el gobierno de Rodríguez Zeledón no se realizaban los cambios esperados. Por ello, la Sociedad de la Unión Católica, fundada en 1889, tomó fuerza y se convirtió en partido político con la firme intención de participar en la arena política, y desde esa trinchera, luchar por los intereses católicos. ${ }^{19}$ Esta participación de la jerarquía de la Iglesia católica se llevó a cabo gracias al propio obispo Thiel, quien actuó de esta manera siguiendo el ejemplo que él conocida del partido Zentrum en su natal Alemania.

El partido tenía como norte y premisa la "responsabilidad civil de defender a la Iglesia", y con ello recuperar todo lo que esta había "perdido" con las leyes decretadas entre 1884-1886. Por ello participaba en las elecciones presidenciales y de congresistas de 1893. La agrupación política buscaba, mediante la responsabilidad ciudadana de todos los católicos, la restauración del universo católico perdido por los hechos desarrollados por los liberales. Esta idea era propuesta desde la colina vaticana a partir de Pio IX y con León XIII se prosiguió su divulgación. Es dentro de este contexto que se debe entender la participación directa del clero y los católicos en política, así como la redacción y publicación de la "Justo Salario".

\section{La propuesta de Mons. Thiel en la carta "Justo Salario"}

En medio de esta realidad económica, social y política de finales del siglo XIX, Thiel decidió publicar su $30^{\text {a }}$ carta pastoral sobre el "Justo Salario" el 5 de septiembre de 1893. Ante este accionar del prelado surgió la siguiente interrogante: ¿En qué medida la carta pastoral sobre el "Justo Salario" de Mons. Thiel fue un intento por implementar la propuesta social de la Iglesia Católica o fue una estrategia electoral dentro de la campaña presidencial en la que participaba el partido Unión Católica, entre 1893-1894? Diversos investigadores, entre la década de 1970 y el 2013, han querido dar respuesta

\footnotetext{
${ }^{18}$ Para comprender lo sucedido sobre dichos hechos se recomienda leer los siguientes textos: Edgar Solano Muñoz, Iglesia, sociedad y relaciones de poder en Costa Rica 1881-1894 (Tesis, Licenciatura en Historia, Universidad Nacional de Costa Rica, 1993). José Aurelio Sandí Morales, "Las leyes anticlericales de 1884 en Costa Rica; una relectura desde otra perspectiva", SIWO 3 (2010): 59-100. José Aurelio Sandí Morales, Estado e Iglesia católica en Costa Rica 1850-1920: en los procesos de control del espacio geográfico y la creación de un modelo de costarricense (Heredia: Publicaciones UNA-SEBILA, 2012).

${ }^{19}$ Esteban Sánchez, "La participación político-partidista de la Iglesia: El Partido Unión Católica y sus estrategias de movilización política en el marco del conflicto entre la Iglesia católica y el Estado liberal en Costa Rica (1889-1898)" (Tesis de Maestría, Universidad de Costa Rica, 2013) 137-213.
} 
a los motivos que incentivaron a Thiel para publicar la "Justo Salario". Las respuestas de los estudiosos han sido variadas. James Backer indicó que el documento respondió más a intereses políticos que religiosos o de solidaridad con los obreros y pobres del país. Para Backer la pastoral fue simplemente un "manifiesto politiquero de la Iglesia en su pugna aguda contra el Estado Liberal". ${ }^{20}$ Para Arnoldo Mora, el texto tenía connotaciones políticas, pero también respondía a la propuesta social del catolicismo propiciado por León XIII. ${ }^{21}$

Esteban Sánchez indicó que la carta pastoral se convirtió en “el derrotero del partido en los siguientes meses de campaña", 22 así como un texto de impacto en el ambiente electoral, por ser visto con gran alarma por parte de los gobernantes liberales. Miguel Picado vio en la publicación el inicio de la Doctrina Social de la Iglesia Católica en Costa Rica. Picado indicó que fue Thiel "el primero en hacer constar que existe una cuestión social en Costa Rica, en indicar que las garantías individuales, meta final del liberalismo son insuficientes". Para este historiador, Thiel comprendió y plasmó en su carta el empobrecimiento de los "destituidos", como él mismo los llamaba, quienes no eran ni "los vagos ni los viciosos", sino los empobrecidos, "víctimas de un sistema social injusto, que los empobrece". ${ }^{23}$ Por ende, para Picado, Thiel adoptó la Rerum Novarum, (la cual estuvo pensada para solucionar los problemas generados en sociedades industrializadas y en Europa), a las dificultades económicas de un país caficultor que formó un proletariado agrícola. ${ }^{24}$

Ahora bien, conociendo de manera sucinta la lectura realizada por varios autores sobre el texto de Thiel, se presentan a continuación los argumentos que los autores de este artículo tienen sobre la "Justo Salario". La 30" carta pastoral fue elaborada bajo dos premisas, que no se anteponen y tampoco se excluyen entre ellas. La primera fue de corte político; esta respondía a la realidad de los hechos acaecidos en la relación Estado-Iglesia en Costa Rica en medio de sus colaboraciones y pugnas. En especial luego de 1884, cuando Thiel veía una pérdida de acción de la fe católica en la sociedad costarricense. La segunda era la visión religiosa-teológica, enfocada en hacer llegar a todos los postulados del papado como parte del proceso de romanización del clero y los fieles, ${ }^{25}$ así como demostrar el papel social que el catolicismo podía jugar en la

\footnotetext{
${ }^{20}$ James Backer, La Iglesia y el sindicalismo en Costa Rica (San José: Editorial Costa Rica, 1975) 49.

${ }^{21}$ Arnoldo Mora, Las fuentes del cristianismo social en Costa Rica (San José: Departamento Ecuménico de Investigaciones (DEI), 1989) 66-72 concuerda con Miguel Picado en verlo como el documento inicial de la Doctrina Social de la Iglesia católica en Costa Rica, pero también indicó que tenía cierto carácter político.

${ }^{22}$ Sánchez, "La participación político-partidista de la Iglesia" 283.

${ }^{23}$ Miguel Picado, La iglesia costarricense: entre Dios y el César (San José: Departamento Ecuménico de Investigaciones (DEI), 1989) 64.

${ }^{24}$ Miguel Picado, La Palabra Social de los obispos costarricenses. Selección de documento de la Iglesia católica costarricense 1893-1981 (San José: Departamento Ecuménico de Investigaciones (DEI), 1982) 17.

${ }_{25}$ Para analizar qué se entendió por romanización del clero y los fieles se recomienda leer: Daniele Menozzi, "Regalità sociale de Cristo e secolarizzazione. Alle origini della Quasprimas", Cristianesimo nella Storia 16 (1995): 79-113; Daniele Menozzi, Sacro Cuore. Un culto tra devozione interiore e restaurazione cristiana della società (Roma: Viella, 2001); Daniele Menozzi, "Un patrono per la Chiesa minacciata dalla Rivoluzione. Nuovi significati del culto di San Giuseppe tra Otto e Novecento", Rivista di Storia del Cristianesimo. I (2005): 39-67; Roberto Rusconi, "Devozioni per il Pontefice e culto per il Papato al tempo
} 
sociedad. Este hecho se unió al intento del obispo por remediar, en la medida de lo posible, el problema de la pobreza que afectaba a gran parte de los costarricenses, esto mediante el intervencionismo estatal. Intervencionismo que se entiende solo si se tiene clara la visión corporativista del cristianismo y las luchas desarrolladas por la jerarquía de la Iglesia católica contra las posturas individualistas defendidas por el liberalismo.

Por ende, el texto no puede ser considerado simplemente como un documento de carácter político; tampoco como una publicación que respondiese únicamente a la intención de difundir las ideas leoninas sobre los obreros o eliminar la pobreza. Thiel era un hombre astuto, por ello, aprovechó el momento y las circunstancias precisas y publicó su carta pastoral. Esto para hacer llegar el mensaje del Papa a Costa Rica, pero también con la clara intención de llevar agua a sus molinos electorales, al presentar el problema de la pobreza existente en el país a causa de los malos gobiernos de los liberales.

Thiel, durante el periodo comprendido entre los años 1886 (año de regreso de su exilio) y 1894, sostuvo una franca lucha con los liberales que gobernaban el país, sin que esto haya dado lugar a la separación entre ambas instituciones. El principal problema con este grupo era su intención de llevar adelante, de una u otra forma, un proceso secularizador de la sociedad. Este hecho no se pudo concretar debido a la realidad social del país, así como al consenso, que de una u otra manera, construyeron los liberales con la jerarquía de la Iglesia católica en temas de común interés. ${ }^{26}$ En medio de esta lucha había un tema en particular que incomodaba más que otros al prelado: la educación religiosa. ${ }^{27} \mathrm{El}$ inconveniente era tan grave que el obispo, entre los años de 1888 y 1892, (año en que se restituyó finalmente la educación religiosa en las escuelas del país), publicó un total de 8 cartas pastorales, las cuales mencionaban la importancia de la educación religiosa en las escuelas públicas para el bien de los feligreses, así como para mantener el orden social y moral del país. Fue por ello que, en 1891, no se le dio mayor "importancia" a la encíclica Rerum Novarum, aun cuando él mismo obligó al clero a leerla a sus fieles en las misas de domingo. No fue sino hasta 1893, luego de haber solucionado el problema de la educación religiosa, que el prelado tomó partes de la Rerum Novarum y la contextualizó a la realidad costarricense, dando como resultado la publicación de la "Justo Salario".

di Pio IX e di Leone XIII nelle pagine di 'La Civiltà Cattolica'", Rivista di Storia del Cristianesimo I, año II (2005): 9-37; Roberto Rusconi, Santo Padre. La santità del papa da san Pietro a Giovanni Paolo II (Roma, Viella, 2010). Rolando Azzi, A neocristandade: um projeto restaurador (Sao Paulo: Paulus, 1994); José Aurelio Sandí Morales, "Costa Rica en la geopolítica de la Santa Sede. La representación papal en Centroamérica entre 1908-1936", Revista Espiga 15.32 (2016): 84-85.

${ }^{26}$ José Aurelio Sandí, Estado e Iglesia católica en Costa Rica 1850-1920.

${ }^{27} \mathrm{Si}$ bien es cierto, Thiel vio en todas las leyes anticlericales decretadas en 1884 un serio problema para la libertad y trabajo evangelizador de la Iglesia católica en estas tierras, lo que más le incomodaba eran las leyes decretadas contra la educación religiosa entre los años de 1884-1886. Entre esos años se estableció la prohibición para el clero de tomar parte en la educación costeada por el Estado, se intentó laicizar la educación, pues se sustituyó las materias de Historia Sagrada y Doctrina Cristiana por las de Moral y Educación Cívica. 
Ante este panorama, Thiel comprendió que su función en Costa Rica no se limitaba únicamente a su labor religiosa. El espectro social, y en particular la ayuda a los sectores más pobres y desprotegidos del país, también eran de su incumbencia. Según Arnoldo Mora el obispo entendió que él no solo debía “[...] luchar por las causas religiosas en las que el pueblo creía, sino que era necesario hacer suyos los intereses sociales y económicos que significaban para el pueblo su dignidad, su justicia, su conciencia de clase". Esta idea la siguió al pie de la letra y cuando buscó un referente en que apoyarse para hacerlo lo encontró en la "Rerum Novarum del 15 de mayo de $1891 " .{ }^{28}$ En este punto se quiere dejar claro que la "Justo Salario" no fue una copia al carbón de la Rerum Novarum. Thiel, como hombre conocedor del ambiente costarricense y su idiosincrasia, evitó hacer mención de temas que en Costa Rica no estaban en discusión. Por ejemplo, no hizo referencia a las huelgas, al socialismo, ni a la abolición de la propiedad privada, temas que en la encíclica leonina sí se trataron. ${ }^{29}$ Esta omisión de temas fue premeditada, lo hizo por prudencia, para no ser catalogado como el portador y promotor de dichas ideas en el país.

El obispo fue claro en su documento desde el principio e indicó cuál sería su tema principal. El texto inició haciendo referencia a la penosa situación que vivía "la clase trabajadora, los peones y artesanos, y sobre los pequeños empleados" del país. Mencionaba que la miseria era tanta que:

Hay familias en los alrededores y en el centro de San José que carecen de lo necesario para alimentar á [sic] sus hijos; envíanles á [sic] las cercas para comer jocotes, al mercado para reunir las cáscaras de naranjas y otras frutas que se botan; no quiero hablar del café, que ya, para muchas familias, es un artículo de lujo que no pueden proporcionarse.

Thiel explicó que tal situación se originó debido a que el salario de un peón agrícola no había aumentado proporcionalmente al costo de la vida y al valor del dinero desde hacía un mínimo de 10 años atrás. ${ }^{30}$

Para Thiel los problemas eran varios. El primero de ellos era la política monetaria del país. Según su análisis, en Costa Rica circulaba una moneda bajo el modelo bimetálico de plata y oro, que luego de 1884 y 1886, se había convertido en una moneda fiduciaria que se basaba en el crédito del país. Esto para el obispo creaba automáticamente dos inconvenientes. El primero era que la moneda no era exportable por ley y el segundo que la plata, por estar sometida actualmente al gran mercado mundial, perdía al menos la mitad del valor que tenía hace diez años. ${ }^{31}$ Además de lo anterior, el prelado culpaba, en parte, de la situación a los cafetaleros. En su opinión,

\footnotetext{
${ }^{28}$ Arnoldo Mora, Las fuentes del cristianismo social en Costa Rica 63.

${ }^{29}$ Leone XIII. Rerum Novarum.

${ }^{30}$ Bernardo Thiel Hoffman, "Trigésima Carta Pastoral: Sobre el justo salario de los jornaleros y artesanos, y otros puntos de actualidad que se relacionan con la situación de los destituidos de bienes de fortuna. Del 5 de septiembre de 1891", La Palabra Social de los obispos costarricenses, comp. Miguel Picado (San José: CECOR, 2007) 1-9.

${ }^{31}$ Thiel Hoffman, "Trigésima Carta Pastoral: Sobre el justo salario de los jornaleros y artesanos” 2.
} 
estos vendían el café a un precio más elevado del real y aprovechaban la ventaja de ser el producto referencial de la economía costarricense, por ende, determinaba el valor de los demás artículos de consumo y comercio en el país.

Thiel no se quedó solo en la crítica, su análisis proponía soluciones. Para el prelado la primera acción que se debía llevar a cabo era lograr que existiese un salario justo, basado en el valor real de la moneda costarricense; esto podía ser posible si "periódicamente, según el alza ó [sic] baja del valor de la moneda" se conformara una "comisión nombrada por la autoridad pública, [o] por los propietarios y trabajadores [...]"32 que estableciera el precio justo por pagar los trabajos realizados. El argumento del obispo respondía directamente a una de las propuestas de León XIII en su encíclica. El Papa expresaba que el salario justo debía estar siempre sobre la base de la justicia natural, pues el pago que no equivalía al trabajo realizado no permitiría la mínima alimentación del obrero y su familia. Por ende, el salario debía ser justo y equitativo, tanto para evitar la pobreza como otros males mayores contra el orden imperante. ${ }^{33}$

Con el fin de combatir la crisis monetaria que atravesaba el país, el prelado propuso un modelo para calcular el salario justo para los obreros. El paulino indicó que hacía diez años, en $1883,5,45$ pesos (\$), eran equivalentes a 5 libras esterlinas, y que, en 1893 , £ 5,00, valían $\$ 12,50$, entiéndase $150 \%$ más. Por ello, afirmó que si para 1893 $\$ 12,50$ equivalía a $\$ 5,45$ en 1883 , y que si para ese año el salario de un jornalero era de $\$ 1$ por día, en 1893 el pago debía de ser de \$2,30. Esto a causa de que este monto le permitiría "cumplir con su decente y humana manutención". Por último, solicitaba que el salario del jornalero, que ganaba antes $\$ 0,75$ al día, aumentara a $\$ 1,70$ y que, de igual manera, "los sueldos de los artesanos, carpinteros, sastres, zapateros, albañiles, deben de aumentarse". ${ }^{34}$ Probablemente la propuesta de Thiel sería refutada por un economista moderno, pero en aquel momento no fue solo la idea del obispo, sino del hombre que mejor conocía la realidad nacional. Para finales del siglo XIX nadie conocía como él, el diario vivir del centro y la periferia del país, esto a causa de sus visitas pastorales. ${ }^{35}$ Por ende, su solución respondía, de una u otra manera, a la realidad de los hechos y a las necesidades del pueblo que él bien conocía.

Las ideas propuestas por Thiel para combatir la crisis no quedaron solamente en un aumento de los salarios. El Ordinario propuso una mejora en la distribución de la tierra, así como la opción de dar "terrenos baldíos" a los pobres, para que estos los trabajaran durante los meses en los cuales los grandes propietarios no los ocupaban como mano de obra durante el desmonte o la recolección del café. Para él si se donaban estas tierras no solamente se generaban propietarios, sino también mano de obra y riqueza para el país.

\footnotetext{
${ }^{32}$ Thiel Hoffman, "Trigésima Carta Pastoral: Sobre el justo salario de los jornaleros y artesanos" 4.

${ }^{33}$ León XIII. Rerum Novarum.

${ }^{34}$ Thiel Hoffman, "Trigésima Carta Pastoral: Sobre el justo salario de los jornaleros y artesanos" 5.

${ }^{35}$ Él mismo indicó en la "Justo Salario" que su conocimiento de la causa respondía a lo que veía en las visitas pastorales realizadas en el país. Thiel Hoffman, "Trigésima Carta Pastoral: Sobre el justo salario de los jornaleros y artesanos" 7. Para tener claro lo que experimentaba y veía Thiel en sus visitas pastorales se recomienda leer: Isabel Herrera, Monseñor Thiel en Costa Rica: visitas pastorales 1880-1901 (Cartago: Ediciones Instituto Tecnológico de Costa Rica, 2009).
} 
Las soluciones propuestas por el Ordinario continuaron. La siguiente fue controlar el valor de los productos de primera necesidad. Thiel mencionaba que el problema radicaba en que antes el cosechero llevaba al mercado su producción y la vendía, pero en años previos a 1893 apareció un grupo de personas que iba directamente donde los cosecheros, le compraban los productos a un precio bajo y luego lo vendían a uno mucho mayor en el mercado. Para Thiel el inconveniente no eran propiamente los intermediarios, sino el egoísmo de estos que subían "los precios de los artículos de primera necesidad á [sic] su antojo", lo cual provocaba un mal mayor al "trabajador y al artesano". Para evitar este mal el obispo propuso crear una comisión que regulase los precios luego de controlar "el valor del dinero, los gastos de acarreo y la ganancia equitativa del comerciante".

Por último, Thiel llamaba la atención al gobierno, a los trabajadores y a los sacerdotes sobre la pobreza en Costa Rica. El obispo solicitaba a los gobernantes no permanecer indiferentes e intervenir. Les solicitó que buscaran una solución a los problemas que él había señalado. Para él, el gobierno estaba en la obligación de tomar partido en el caso, ya que su rol en la sociedad era de "auxiliar, favorecer y proteger especialmente al necesitado y con buenas leyes y disposiciones evitar cualquier abuso." A los trabajadores les indicó que, si "el auxilio de la autoridad civil" no llegaba tenían "el derecho de formar entre ellos sus propias asociaciones y juntar sus fuerzas de modo que puedan animosamente liberarse de la injusta e intolerable opresión”. Recordó al clero ser ellos los principales difusores de la doctrina del Papa y de lo escrito en su carta pastoral. Para ello les dijo que la Iglesia "[...] no enseña al hombre cruzar los brazos y aguardar el auxilio de otra parte sin moverse [...], sino que Ella nos enseña a trabajar activamente buscando los medios para remediar los males". ${ }^{36}$

La solicitud al Estado de intervenir en la economía y respaldar el derecho de los trabajadores a unirse para buscar mejores condiciones son muestras inequívocas de que la Rerum Novarum fue luz y guía para Thiel en la redacción de su escrito. La idea de reproducir las propuestas leoninas fue una de las premisas de Thiel, pero también existieron otros propósitos.

La carta presenta tres realidades del país que el obispo quiso dejar plasmadas. La primera fue de índole religiosa, pues demostró su unidad en pensamiento y acción con el Papa al secundar y difundir la doctrina social propuesta por Pecci en la Rerum Novarum, argumento del cual ya se habló. La segunda fue presentar la pobreza existente en Costa Rica. Esto lo demostró de manera clara, pues los argumentos citados por Thiel eran ciertos. La pobreza en Costa Rica era un hecho real, la concentración de tierras en pocas manos avanzaba de manera galopante en el país y el mendigar en los mercados era ya una costumbre diaria a finales del siglo XIX. La tercera realidad fue atacar de manera abierta a los gobiernos liberales y poner en evidencia los males del sistema liberal impuesto en el país. Esto lo desarrolló con la obvia intención de hacer notar las malas gestiones de los liberales en el poder, esto a escasos cinco meses para las votaciones de primer grado en las cuales se elegiría a los representantes que designarían al nuevo presidente.

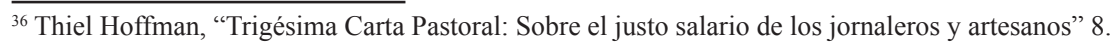


Lo anterior deja clara la visión política del documento. Muestra de ello es que, de los nueve puntos presentados en el programa de gobierno de Unión Católica, al menos cinco fueron temas tratados en la "Justo Salario". El Ordinario, en la carta pastoral, llamaba a la intervención del Estado, pero siempre dentro de una "democracia liberal" y agroexportadora. Por su parte, el programa de gobierno indicaba que si ellos triunfaban tendrían "por base la Constitución Política que actualmente nos rige" (art. I), ${ }^{37}$ la cual era netamente liberal. En síntesis, Thiel, sus sacerdotes y los políticoscatólicos planteaban una intervención mayor del Estado en la economía, sin salirse del status quo. Por ejemplo, la "Justo Salario" y el programa de gobierno plantearon los siguientes postulados en común: 1) solucionar el problema de la moneda, lo cual se haría mediante el establecimiento del patrón oro, con el pago de la deuda externa y limitando la acuñación de plata (Art. IV (del programa de gobierno)), 2) proteger la agricultura y ganadería en general, especialmente el café y los sembradíos de tabaco y caña de azúcar (Art. V), 3) proteger e incentivar la cría de ganado para que satisfaga las necesidades del país (Art. VII), y por último, procurar el crecimiento de la industria nacional en ramas como: la sastrería, la zapatería, la carpintería y la talabartería (Art. VIII). Esto se proponía para mejorar las condiciones de los trabajadores mediante un pago debido, así como cuidar los precios de los productos básicos y una mejor distribución de la tierra.

Todos estos puntos dejan clara la postura de Thiel. El documento tenía componentes políticos, pero también religiosos. Esto era lo que lo hacía más difícil de contrarrestar, ya que por un lado muchos podían sospechar de las intenciones políticas del documento, pero por el otro lado, Thiel no decía nada alejado de la realidad, unido a su labor y responsabilidad de pastor de sus fieles, que en su mayoría eran pobres y por los cuales él debía levantar la voz. Sin embargo, los liberales no esperaron mucho tiempo para devolver la afrenta al obispo.

\section{La respuesta de los liberales a la propuesta política- religiosa de Mons. Thiel}

Los liberales del país respondieron de diferentes maneras a Mons. Thiel su atrevida proposición política-económica. Por un lado, publicaron artículos en periódico y por el otro los gobernantes le dirigieron cartas de manera directa al obispo. La pastoral de Thiel se publicó el martes 5 de septiembre de 1893, y fue leída según la norma el domingo 10 de septiembre en todas las parroquias del país. Las réplicas aparecieron en los cotidianos desde el 12 hasta el 17 de septiembre. Tres periódicos hicieron frente común a lo planteado por Thiel, estos fueron: El Heraldo de Costa Rica, Prensa Libre y La República. Los tres diarios estaban vinculados al liberalismo y de una u otra manera eran aliados al gobierno.

El argumento constante de las publicaciones por parte de los periodistas fue que Thiel mentía, creaba fábulas y exageraba la realidad de los hechos. Por ejemplo, en La Prensa Libre del 13 de septiembre se indicó que: "Quien quiera que lea lo que

${ }^{37}$ Sánchez, "La participación político-partidista de la Iglesia” 287. 
antecede tendrá que convenir en que el señor Thiel se ha inspirado en fábula para soflamar las pasiones de los obreros lo de los jocotes no pasa, Illmo. Sr.! Lo de las cáscaras, menos! La situación económica no es tranquilizadora ciertamente; pero de ella á [sic] la pintada en la pastoral, hay enorme distancia". ${ }^{38}$

Unido a lo anterior, el mismo periódico en su edición del 15 de septiembre continúo desmintiendo los planteamientos del obispo. En esta ocasión hizo referencia a la falsedad y exageración del ejemplo de los jocotes, el periódico indicó que: "Si la especie de los jocotes fuese cierta; [...] los infelices niños tendrían que morirse de hambre, pues esta fruta solo se produce durante dos meses en el año. ¿Qué harían en los diez meses restantes $?^{39}$ Esta posición de llamar fantasiosos los argumentos de Thiel se unió a contradicciones de los tres periódicos que lo atacaron. Por ejemplo, la misma Prensa Libre se contradijo al decir que la situación presentada por Thiel era una fábula, pues "El salario guarda proporción hoy con el cambio, como lo guardaba ahora quince o más años, cuando el oro circulaba". ${ }^{40}$ Esto era irreal, no solo por el hecho de que el salario de un jornalero no cambió en mucho a lo largo de las dos últimas décadas del siglo XIX, sino también porque la misma Prensa Libre había indicado que la situación económica no era tranquilizadora, esto a causa de que pobreza iba en aumento. Esta realidad la confirmó el periódico denominado $\mathrm{El}$ Heraldo de Costa Rica al indicar que "el estudio económico del señor Obispo tenga mucho de cierto", por ende, cómo es posible que el obispo por un lado tenga razón y a la vez no. Esto dejaba entrever que la pobreza avanzaba y era una realidad en la Costa Rica del periodo, pero que los grupos de poder aliados al liberalismo lo veían como un fenómeno aislado o sin mayor importancia, y que debía de ser atendido por la Iglesia y no necesariamente por la estructura estatal que carecía de herramientas para combatirla eficazmente.

Para los liberales la intención del obispo era llevar votos a su partido político. El Heraldo de Costa Rica indicaba que Thiel publicó el documento en un momento crítico para la República, pues lo hacía a pocos meses de las votaciones. ${ }^{41}$ Por su parte, la Prensa Libre precisaba que el texto respondía al “[...] aguijón político tratando de abrirse paso por en medio del cuerpo social, en vísperas de la elección del primer mandatario de la Republica" ${ }^{42}$ Aún más, para ellos, la verdadera intención del Obispo era “[...] jocotear en la próxima situación política, y que el grito de la Unión Católica sea: ¡A los jocotes del señor Obispo!” ${ }^{43}$ Ante esta situación tan clara para ellos y como buenos liberales, la Prensa Libre llamó la atención a La República y a El Heraldo de Costa Rica, para no quedarse en silencio y atacar al obispo. Este cotidiano indicaba que La República no había dicho nada ${ }^{44}$ y lo expresado por El Heraldo de Costa Rica, era

\footnotetext{
38 “¿Vuestra espada tiene punta?”, Prensa Libre, (San José) 13 de septiembre de 1893.

39 "La pasto.......bravo", Prensa libre, (San José) 15 de septiembre de 1893.

40 “QVuestra espada tiene punta?”.

41 "La Carta Pastoral”, El Heraldo de Costa Rica, (San José) 12 de septiembre de 1893.

42 “¿Vuestra espada tiene punta?”.

43 “Obispo y sus jocotes”, Prensa Libre, (San José) 17 de septiembre de 1893.

${ }^{44}$ Esto no es del todo cierto. La República había publicado el 13 de septiembre de 1893 un breve artículo
} 
"pura pirotecnia y escarneo [sic] literario, revoloteo inofensivo de mariposa", ${ }^{45}$ ante el intento del obispo de robar la tranquilidad y paz que siempre habían caracterizado a Costa Rica, a causa de los intereses e influencia que sobre Thiel ejercía el "cesarismo romano". ${ }^{46}$

Los tres periódicos liberales al unísono plantearon un argumento común contra el diocesano. Este era que el Ordinario de San José debía centrarse única y exclusivamente en predicar, trabajar dentro de los templos y dedicarse a la caridad, labor que debía desarrollar los fieles y él, como su pastor. El primero en recomendar tal tipo de comportamiento fue El Heraldo de Costa Rica, al indicar que:

[...] con franqueza: creemos que la misión evangélica del Ilustrísimo señor Thiel habría quedado bien cumplida con predicar la justicia y la caridad, con producirse en la Cátedra contra la vagancia, el lujo y los vicios corruptores del alma y productores de la miseria, con estimular el amor al trabajo honrado, y á [sic] la fraternidad y á [sic] la concordia entre los costarricenses. ${ }^{47}$

Por su parte, la Prensa Libre además de mandarlo a trabajar dentro de los templos le cuestionaba su moral. Ellos le recordaron al obispo lo siguiente:

Clama el prelado contra la exigüidad de los salarios de los pobres y manifiesta cuanto en su concepto es lo que deben ganar. Ha debido, para demostrar que la justicia entra por casa, hacer patente que á [sic] dicha cuantía ha alcanzado ya los jornales de los trabajadores que están levantado actualmente el templo de la Merced. ¿podría decirnos cuanto [sic] pagan a sus operarios, Illmo. Señor? ${ }^{48}$

El periódico continuó su ataque a la moral del obispo. La Prensa Libre le preguntó que: ¿Cómo explicarnos si nó [sic] que en medio de situación tan pavorosa de miseria el amantísimo pastor del rebaño" a pesar de haber realizado votos de pobreza poseía acciones del Banco de Costa Rica y no repartía parte los dividendos que esto le generaba entre los que "[...] para vivir tienen que merodear jocotes en los encercados o recoger en el mercado cascaras que tal vez han sido pisadas por plantas quizá no tan limpias con las de su Ilma?". ${ }^{49}$

Por último, le recordaron al obispo una "verdad" no tan cierta sobre la pobreza en el país. Según los periódicos la miseria en Costa Rica no era un problema así de grande como él lo presentaba, pues no había tanta pobreza ni mucho menos miseria. Para ellos el problema eran los "Brazos que faltan" para realizar los trabajos que había

donde cuestionaba la moral del obispo y lo invitaba a socorrer a los pobres, aunque en Costa Rica para ellos no había miseria. Véase: "El Señor Obispo", La República, (San José) 13 de septiembre de 1893.

45 "La pasto...... bravo".

46 "La pasto...... bravo".

47 "La Carta Pastoral".

48 "La pasto...... bravo".

49 "La pasto...... bravo". 
en el territorio costarricense. ${ }^{50}$ La Prensa Libre argumentaba que "La miseria y el hambre todavía, á [sic] Dios gracias, no han asomado aquí su descarnada faz", ${ }^{51}$ con el fin de dejar claro que todo lo expuesto por el Ordinario era un sin sentido. Ellos expresaban que la protección solicitada por el obispo para los trabajadores era una petición irracional, pues era una "protección que no necesitan ni ha solicitado". 52 Por último, le indicaba que la poca pobreza que había era "fácil" de solucionar. Para ellos la pobreza se podía erradicar mediante acciones de los ricos y del propio obispo. El periódico La República indicaba que, si los ricos socorrían "á [sic] los pobres y que si el señor Obispo tiene en los bancos buenas cantidades, es bueno que entren en las cajas de beneficencia para socorrer á los pobres", y con ello se eliminaría la pobreza, ya que "Aquí no hay miseria, señor". ${ }^{3}$

Este comportamiento mostrado por quienes publicaron sus opiniones en los periódicos fue fiel reflejo de la realidad política de los gobernantes. El gobierno, al igual que sus aliados, no tenía la capacidad para combatir la pobreza, al punto que mejor se lo dejaban a la filantropía de los ricos y a la caridad cristiana del obispo y sus fieles. Los periódicos se dedicaron a negar y refutar todo lo indicado por el prelado, a pesar de que era una realidad que se veía en el diario vivir del periodo y que, además, trabajos históricos recientes la muestran como un hecho verdadero. Asimismo, es irrefutable la confrontación del grupo afín a la política liberal y al modelo agro-exportador ante la mínima crítica, ya que estos no pensaron dos veces en atacar a quien cuestionaba su modelo. Argumentaron que la economía no se encontraba "tan" mal, que la pobreza y la miseria no campeaban por el suelo costarricense. Esto les permitía despojarse de las responsabilidades de buscar políticas que corrigieran el mal social que aquejaba a la mayoría de los costarricenses. Por último, le recomendaron al Ordinario que la realidad presentada por él era "inexistente", por ende, lo mejor que podía hacer era dedicarse exclusivamente a hacer sus comentarios y acciones de caridad dentro de los templos y las sacristías, y no meterse a hablar y tergiversar la realidad económica del país. Lo particular de esta posición es que fue exactamente la misma que adoptaron los gobernantes, pues nunca plantearon una propuesta para corregir el mal, solo amenazas por haber presentado el panorama real de la Costa Rica de fines del siglo XIX.

La respuesta de los gobernantes ante lo escrito por Thiel fue directa, contundente y amenazante, pero nunca propositiva para combatir el problema planteado. El Ministro de Culto, Manuel V. Jiménez, en una carta enviado al prelado le recordó que el poder civil en su obligación de:

[...] mantener el orden y la tranquilidad de los pueblos, se vé [sic] en la necesidad de llamar seriamente la atención de Ud., hacia el procedimiento por Ud, empleado, dando publicidad a su citada Pastoral y á [sic] otras anteriores, sin haber obtenido previamente la indispensable autorización del Poder Ejecutivo,

\footnotetext{
50 “QVuestra espada tiene punta?”, Prensa Libre, (San José) 13 de septiembre de 1893.

51 “¿Vuestra espada tiene punta?”.

52 “¿Vuestra espada tiene punta?”.

53 “El Señor Obispo".
} 
hácia [sic] doctrinas tan erróneas, como la que la autoridad debe fijar el precio de los trabajadores, tan antieconómicas como la que establesca [sic] el valor de los artículos de primera necesidad tan inconvenientes, como la exitar [sic] á los obreros á [sic] formar entre ellos sus propias asociaciones y juntar sus fuerzas de modo que puedan animosamente libertarse de la injusta é [sic] intolerable opresión que supone en los patrones. ${ }^{54}$

La misiva dada por Jiménez dejó claros dos elementos fundamentales que se amalgaman en la relación Estado-Iglesia para el caso costarricense. La primera era amenazar al obispo por redactar y publicar un texto sin el permiso del gobierno civil. Esto al recordarle una ley del año 1885, que imponía como obligación una revisión previa por parte de las autoridades estatales a los escritos eclesiásticos antes de su publicación. Legislación que fue decretada por el grupo liberal que gobernó entre los años de 1882-1889, en un intento más por controlar a la jerarquía católica del país. Operación (controlar a los sacerdotes) que no abandonaron en el gobierno de Rodríguez a pesar de que su victoria se dio gracias a la ayuda del clero. El segundo punto es que el escrito de Thiel fue visto como un ataque directo al sistema económico imperante en el país. Arremetida que los liberales no iban a aceptar, pues si bien Rodríguez Zeledón, su yerno Iglesias Castro y su propio Ministro de Culto tuvieron como aliados en su momento a los católicos, con fines electorales, ellos seguían siendo liberales, y por ende, no aceptarían por ningún motivo que el obispo les indicase cómo se debía de gobernar el país y muchísimo menos en aspectos político-económicos. Esto muestra que la clase gobernante veía a los sacerdotes como aliados y no como cuestionadores del orden establecido. Por ende, acá se demuestra la inexistencia de un proceso secularizador de la sociedad costarricense, ya que los liberales lo que querían era tener a su favor la opinión del presbiterio católico y no alejarse de ellos para propiciar la separación de poderes.

Muestra del argumento anterior, fue el reproche hecho por Jiménez al obispo por su intromisión en aspectos que no le competían. Este "regaño" fue un tanto exagerado al inculpar al diocesano de sembrar en los trabajadores la idea de unirse para que desarrollaran " $[. .$.$] tendencias socialistas que entrañan, profundas perturbaciones en$ la marcha de los interese recíprocos de la propiedad y el trabajo y no se compadecen con la misión conciliadora del Pastor". A causa de este "mal" proceder, el gobierno le recordó que su principal pecado fue no pedir el permiso, por el cual: "En consecuencia, el gobierno espera de Ud., que en cumplimiento de estrictas disposiciones legales en adelante no dé publicidad á [sic] ningún documento sujeto al "pase" respectivo, sin llenar previamente esta formalidad". ${ }^{55}$ Para ellos esta queja era fundamental, si Thiel hubiese pedido el permiso respectivo para su carta, las ideas socialistas que él "propagaba" no hubiesen visto la luz, y se hubiese evitado que se esparcieran por el país, "perturbando" el ambiente de "paz y tranquilidad" que se vivía en Costa Rica, según los gobernantes. ${ }^{56}$ De nueva cuenta, esto es muestra de la relación existente entre

\footnotetext{
${ }^{54}$ Archivo Histórico Arquidiocesano Bernardo Augusto Thiel (AHABAT), Fondos Antiguos, sin indizar. Caja 19, folder 1893. San José, 14 de septiembre de 1893. Ff. 44-45.

${ }^{55}$ AHABAT, Fondos Antiguos, sin indizar. Caja 19, folder 1893. San José, 14 de septiembre de 1893. Ff. 44-45.

${ }^{56}$ Ante tal acusación el descargo de Thiel fue claro. El diocesano le indicó tanto al presidente Rodríguez
} 
los gobernantes liberales y la jerarquía católica a finales del siglo XIX, los primeros más que alejarse de esta institución y propiciar la secularización de la sociedad lo que deseaban era controlar a su miembros y que estos fuesen sus aliados, colaboradores y difusores de sus políticas, no cuestionadores de ellas.

Un dato por resaltar es que tanto el gobierno como los periódicos ${ }^{57}$ inculparon a Thiel de propagar ideas socialistas. ${ }^{58}$ Esta fue una acusación sin fundamentos, el prelado nunca mencionó esta palabra, así como tampoco habló de huelga o de abolición de la propiedad privada. Él conocía claramente la realidad del país, por ende, nunca usó estos conceptos, pues no eran tema de discusión en Costa Rica. Aun así, los liberales lo culparon de una idea que él nunca escribió, ni incentivó, ya que como religioso romanizado que era tenía claro que para la Iglesia en general el socialismo era pecado. Ahora bien, surgen varias dudas luego de conocer los argumentos y los ataques que dio y recibió el prelado. La primera es: ¿cuál era la intención del documento de Thiel dentro del marco del sistema económico imperante en Costa Rica, si su propio partido no planteaba un cambio radical en este? Se sabe que la publicación tuvo intenciones políticas y religiosas, pero cuáles eran las económicas, ¿solamente aumentar el salario de los jornaleros? Esto lo respondió en la carta enviada por él al presidente de la República, José Joaquín Rodríguez, el 15 de septiembre de 1893, en la cual explicaba el motivo de su documento.

Thiel le explicó al presidente que su texto solo pretendía presentar los problemas existentes en el país y las posibles soluciones. Para ello le expuso dos ideas, la primera era el intervencionismo estatal ante el liberalismo reinante en la economía nacional, y la segunda modificar la política monetaria de Costa Rica a través del intervencionismo propuesto por él. En la misma carta del 15 de septiembre de 1893, Thiel indicó que urgía un intervencionismo estatal, ya que "La libertad desmedida y sin límites en materia de economía nos arrastra al pauperismo y a una esclavitud paliada". ${ }^{59}$ Además, explicaba que la crisis monetaria atacaba a más de tres mil trabajadores de la clase media, empleados públicos y al comercio en general. Para el obispo el problema

en la carta del 15 de septiembre como a Rafael Iglesia, Ministro de Guerra y Marina, el 17 de septiembre, que él envió dicho texto y que no recibió respuesta alguna y por eso procedió a publicarla. Ante tal afirmación Rodríguez e Iglesia no respondieron nada. AHABAT. Fondos Antiguos, Caja 304. San José, 15 de septiembre de 1893. f. 17, y AHABAT. Fondos Antiguos, Caja 304. San José, 17 de septiembre de 1893. f. 24.

${ }^{57}$ De cinco artículos publicados en contra de la "Justo Salario", dos lo acusaron de favorecer las ideas socialistas en el país. Por ejemplo, en El Heraldo de Costa Rica se indicó que por los argumentos de Thiel se podía caer en la "imitación de países diametralmente distintos del nuestro, [se] emprendan el peligroso camino de las huelgas y el socialismo". "La Carta Pastoral", El Heraldo de Costa Rica, (San José) 12 de septiembre de 1893. Por su parte, en la Prensa Libre se indicó que: "Deje el prelado que cada individuo le ponga á [sic] su trabajo el valor que él cree que su trabajo tiene y no derrame en el aprisco la tremenda semilla del socialismo". "La pasto......bravo".

${ }^{58}$ Como bien lo dice Miguel Picado a Mons. Thiel "le corresponde la honra de ser el primer cristiano costarricense calumniado con el epíteto de socialista". Dicha calumnia se volvió, en Costa Rica, un ataque que se lanza aún hoy, sin "el menor respeto a la verdad ni deseo de comprobación contra aquél que procure llevar al terreno de los hechos los planteamientos de justicia social". Picado, La iglesia costarricense: entre Dios y el César, 68.

${ }^{59}$ AHABAT. Fondos Antiguos, Caja 304. San José, 15 de septiembre de 1893. f. 22. 
radicaba en lo "agiotaje de las letras de cambio, con un alto cambio que significa una baja correspondiente en el valor de nuestra moneda circulante". Esta dificultad inducía al alza "[...] de muchos artículos indispensables para la clase media y provoca una fluctuación continua, inseguridad y perturbación en las transacciones generales". Por último, hizo hincapié en "el alto precio de los alquileres de casa que consumen á [sic] veces la tercera parte sino la mitad del sueldo" $"$. Según Thiel, este ejemplo era muestra de la crisis que atravesaba la economía costarricense por falta de un control estatal.

Ante este panorama el obispo le propuso al presidente que para solucionar el problema la moneda costarricense debía "tener el valor que antes tenía en comparación de la moneda de oro". Para él, esto se lograba si el Estado y en especial el presidente mediaban en la economía nacional, para crear una comisión que regulara el valor de la moneda, y consecuentemente, el precio de los bienes primarios, para ello le citaba el artículo $113^{61}$ de la Constitución Política. Según el raciocinio de Thiel “[...] las acciones privadas que han destruido nuestro equilibrio social, producen realmente daño o perjuicio de terceros -en el presente caso á [sic] la clase media-”, debían de ser atacadas. Para ello se amparaba en el Artículo 50 de la Constitución, ya que según su argumento el intervencionismo era para el bien de todos, pues procuraba el control de los precios de los bienes de primera necesidad. Lo cual recuperaría la justicia social que imperaba en Costa Rica en años anteriores, expresaba el prelado. ${ }^{62}$

Este argumento intervencionista de Thiel, el cual hacía referencia constantemente a la Constitución Política, respondía a dos objetivos en particular. El primero, demostrar que la Constitución amparaba la intervención estatal en la economía para el bien de la mayoría. El segundo cometido era evitar ser visto o presentado como revolucionario o "antisistema". Él defendía la intervención para llevar adelante la justicia social, pero siempre bajo las normas y lineamientos establecidos por la Constitución liberal de 1871. De ella volvió a citar los artículos 27, 29, 73, 50 e 113, que, de manera general, consolidaban la inviolabilidad de la propiedad privada (acá utilizaba ideas de la Rerum Novarum), el principio de que todo hombre era libre y no podía ser esclavo de ningún otro, así como la libertad de imprenta. Todas estas eran libertades liberales. Lo novedoso de la propuesta de Thiel fue precisamente el intervencionismo estatal que solicitaba. Para él, la moneda debía estar regulada por una comisión nombrada por la autoridad, aun esto dentro de un contexto de Estado liberal de tipo laizzesferiano. En su carta, Thiel lo que explicaba era la devaluación de la moneda costarricense que lleva a una inmediata inflación. Este problema no fue nuevo en el país, pues ya se había dado en la década de 1870. Para el periodo en el que Thiel expuso el problema, el nuevo presidente Rafael Iglesias (1894-1902) tardó mucho tiempo en establecer el patrón oro y el cambio de moneda (del peso al

\footnotetext{
${ }^{60}$ AHABAT. Fondos Antiguos, Caja 304. San José, 15 de septiembre de 1893. f. 18.

${ }^{61}$ Los artículos de la Constitución Política que citó el obispo en su carta al presidente tenían el propósito de indicarle al mandatario que existía un marco legal que le permitía intervenir en la economía de la nación para el bien de los menos favorecidos. Para observar qué indicaban dichos artículos se recomienda leer: Clotilde Obregón (ed.), Las constituciones de Costa Rica (Tomo IV) (San José: Editorial Universidad de Costa Rica, 2007).

${ }^{62}$ AHABAT. Fondos Antiguos, Caja 304. San José, 15 de septiembre de 1893. f. 20.
} 
colón). Aunado a este hecho, cuando se da el cambio topó con la mala suerte de que coincidía con la crisis finisecular (1896-1906). ${ }^{63}$

Por último, y al observar lo complejo del ambiente electoral y las presiones del gobierno Thiel buscó limar las asperezas con este. Lo procuró por medio del envío de una nueva carta, el 17 septiembre y dirigida a Rafael Iglesias Castro, ministro de Guerra. En esta, además de explicarle el motivo de la "Justo Salario", le indicó que en ese momento quería "reparar esta disonancia, encaminando las cosas inmediatamente según la intención del Gobierno", pues su carta pastoral lo que perseguía era un interés "económico [que debía de] estar en armonia [sic] con las miras del Gobierno. Siendo esta armonia [sic] lo más importante por el momento". ${ }^{64}$ De esta manera, se concluyó en parte la pugna suscitada por la publicación de la 30 carta pastoral de Thiel. Aunque la lucha política y las pugnas entre los gobernantes y la jerarquía católica no concluyeron con dichas cartas, ya que el propio Thiel no pudo llevar adelante su plan de justicia social por los sucesos de fraude y presiones gubernamentales contra el partido católico, acaecidos a sus militantes y a él mismo entre septiembre de 1893 y mayo de 1894. Esto propició que las principales figuras del país en el poder político y eclesiástico buscaran un consenso entre las partes. Al llegar a ese acuerdo luego de 1894, el papel de Thiel en la sociedad costarricense fue más de índole religioso que social, ${ }^{65}$ hasta 1901 año de su muerte.

\section{Conclusiones}

Thiel publicó la carta en medio de un ambiente político bajo dos premisas claras, una política-electoral y otra religiosa. La política-electoral respondía a su interés de llevar votantes a su partido Unión Católica, mediante una crítica fuerte y directa al modelo económico que los liberales habían implementado en el país. La idea religiosa responde a su visión romanizadora del presbiterado y de los fieles, mediante la difusión de los escritos y pensamientos del Papa en esta tierra. Si bien la Rerum Novarum había sido publicada en 1891, la carta pastoral de septiembre de 1893 tomó de nuevo el documento leonino como guía en su redacción, para dejar claros sus fines religiosos y políticos. De igual manera, para presentar la propuesta corporativista del credo católico como modelo de bien común de la sociedad.

La escritura y publicación de la "Justo Salario" generó controversia entre propios y extraños, pero principalmente en el grupo liberal que gobernaba y manejaba ciertos periódicos en el país. El temor por la crítica directa y veraz de Thiel provocó que el prelado terminara siendo acusado como propagador de ideas socialistas. Para los

\footnotetext{
${ }^{63}$ Andrea Montero, "De grano de oro a grano de cobre: Los efectos de la primera crisis de sobreproducción en la Industria cafetalera costarricense (1896-1910)", Revista de Historia. 63-64 (2011): 101-117.

${ }^{64}$ AHABAT. Fondos Antiguos, Caja 304. San José, 17 de septiembre de 1893. f. 24.

${ }^{65}$ Sobre esta realidad y los problemas que tuvo que enfrentar Mons. Thiel para llevar adelante su plan político-social se recomienda leer: Mora, Las fuentes del cristianismo social en Costa Rica; Sánchez, "La participación político-partidista de la Iglesia" y José Aurelio Sandí Morales, "La Santa Sede in Costa Rica 1870-1936. Il rapporto politico-religioso e diplomatico tra il governo del Costa Rica, la gerarchia cattolica del Paese e la Santa Sede nel periodo liberale costaricano" (Tesi di dottorato, Scuola Normale Superiore, 2017).
} 
liberales pedir, aunque fuera una mínima intervención estatal como lo hizo Thiel, era sinónimo de socialismo, el problema es que esto estaba muy alejado de la realidad. Thiel, por su fe, su adhesión al Obispo de Roma y hasta por su propia forma de ser no tuvo en ningún momento ideas cercanas al socialismo, la acusación fue simplemente un ataque sin fundamentos más, por parte de los liberales. Estos dentro de la dinámica de atacar la propuesta del obispo también mintieron e invisibilizaron la realidad de Costa Rica, al indicar que la pobreza era casi inexistente en un país sometido a un modelo agro-exportador. Por ende, se puede determinar que la respuesta ante la carta pastoral, por parte de los liberales, se valió de artimañas y mentiras. Su intención y su forma de defenderse fue mediante la deslegitimación de los argumentos de Thiel y la tergiversación de la realidad; en vez de entrar en una discusión política que generara propuestas para remediar un mal que de una u otra manera ellos mismos reconocían, lo que prefirieron invisibilizar la pobreza en Costa Rica y descalificar los argumentos del obispo.

Dentro de esta visión, para los liberales los pocos pobres que existían debían ser atendidos por la Iglesia y esta debía trabajar solo dentro de los templos. Bajo estas dos premisas (por cierto, muy liberales), los editores de los periódicos, quienes atacaron al obispo por su osada propuesta, indicaban que era obligación de la Iglesia velar por los pobres y desvalidos. La caridad era ya una práctica común en los católicos costarricense, Javier Rodríguez Sancho indicó que: “Tanto la Iglesia Católica como algunas personas e instituciones eran quienes ejercían esa función social por medio de la filantropía y la beneficencia desde las postrimerías del siglo XIX" ${ }^{66}$ Ejemplos de lo anterior se encuentran en los casos del Hospicio de Huérfanos, el cual fue fundado en 1869 , pero a mediados de la década de 1880, su administración fue entregada a Mons. Thiel, quien colocó a la "Sociedad Católica de las Señoras de la Caridad de San Vicente de Paúl", como la encargada de realizar tal labor. También se encontraba el caso del Hospital San Juan de Dios el cual era atendido, desde 1868, por las Hermanas de Caridad. ${ }^{67}$ Por ende, la "recomendación" dada por los editores y los gobernantes era más bien una amenaza para el obispo, a quien se le indicaba que era su obligación atender a los menos favorecidos, así como limitarse a que sus discursos se quedaran dentro de los templos y no salieran de ahí. Al parecer, el temor a que se presentara y difundiera públicamente la realidad de un país, cosa que a los liberales no les favorecía, fue tal, que a Thiel hasta le prohibieron uno de los principios fundamentales del liberalismo: la libertad de expresión, pues le recordaron que debía primero pedir permiso al gobierno central antes de publicar cualquier tipo de documento, esto a pesar de que no existía el Concordato desde 1884. Esto fue una muestra clara del tipo de liberales que gobernaba el país, quienes más que libertad buscaban control, tanto dentro de la sociedad como de la Iglesia católica y en particular de su jerarquía.

\footnotetext{
${ }^{66}$ Javier Rodríguez Sancho, "El estado en Costa Rica, la iniciativa pública y privada frente al problema de la pobreza urbana. San José (1890-1930)", Anuario de Estudios Centroamericanos, Universidad de Costa Rica 1-2.26 (2000): 58.

${ }^{67}$ Arnulfo Carmona B., Reseña del Hospital San Juan de Dios, www.binasss.sa.cr/revistas/hospitales/art72. pdf 14 (2017).
} 
Esto deja claro la realidad de la relación Iglesia-Estado en Costa Rica a finales del siglo XIX. Si bien el grupo que gobernaba tuvo como aliado al catolicismo para tomar el poder en 1889, no iba a permitir que los sacerdotes los contrariaran en su proceder como gobernantes. Más bien, esperaba del presbiterado un apoyo irrestricto a sus políticas y determinaciones. Esto muestra que nunca hubo una tentativa real de secularizar la sociedad costarricense, pues como bien se observó el Estado utilizaba ciertas actividades católicas para contrarrestar los males que aquejaban al país. En este caso, entiéndase la caridad cristiana mediante la creación y asistencia a lugares de acogida para pobres, huérfanos, viudas y enfermos. ${ }^{68}$

La queja de Thiel contra las injusticias sociales generadas por el modelo laizzesferiano implementado en Costa Rica fue la primera que se externó desde la jerarquía católica costarricense. Lo anterior deja en claro su posición y labor como Obispo y no solo sus intereses políticos, la propuesta intervencionista de Thiel respondía a la visión corporativa de la Iglesia católica. El prelado fue claro en su carta, atacó el "pecado social" que se estaba dando contra la mayoría de la sociedad. Por este motivo, el Ordinario de San José les solicitó a los gobernantes actuar para el bien de todos, en forma corporativa, en función de evitar que las propuestas liberales-individualistas produjeran ganancias solo a un pequeño grupo de personas, en detrimento de la mayoría de la población. Por ende, es también dentro esta visión que la propuesta social de la jerarquía católica fue difundida por primera vez en Costa Rica en la "Justo Salario", por parte de Mons. Thiel en el año de 1893. Entender los motivos por los cuales Mons. Thiel no pudo desarrollar su plan social es una inquietud que se desprende de esta investigación, pero por ser un tema tan amplio deberá desarrollarse en otro momento.

\section{Bibliografía}

\section{Fuente primaria}

\section{Documentos de Archivo}

Archivo Histórico Arquidiocesano Bernardo Augusto Thiel (AHABAT). Fondos Antiguos, Caja 304.

Archivo Histórico Arquidiocesano Bernardo Augusto Thiel (AHABAT). Fondos Antiguos, Cartas Pastorales de Mons. Thiel, Stork, Castro. Caja \# 4.

\section{Artículos de prensa}

Prensa Libre (San José) 1893.

\footnotetext{
${ }^{68}$ Para ver este comportamiento se recomienda la lectura de: Luis Osvaldo Barrantes y otros, "Política social, beneficencia y abandono de niños en Costa Rica (1890-1930)" (Tesis, Licenciatura en Historia, Universidad de Costa Rica, 1995) 68.
} 
El Heraldo de Costa Rica (San José) 1893.

La República (San José) 1893.

\section{Fuente secundaria}

\section{Libros}

Azzi, Rolando. A neocristandade: um projeto restaurador. Sao Paulo: Ediciones Paulus, 1994.

Backer, James. La Iglesia y el sindicalismo en Costa Rica. San José: Editorial Costa Rica, 1975.

Casey, Jeffrey. Limón: 1880-1940. Un estudio de la Industria bananera en Costa Rica. San José: Editorial Costa Rica, 1978.

Chenu, Marie-Dominique. La Dotrina Sociale della Chiesa, origine e sviluppo (18911971). Brescia: Queriniana, 1982.

Frigato, Sabino. La difficle democracia. La dottrina sociale della Chiesa da Leone XIII a Pio XII (1878-1958). Torino: Editrice EFETA, 2007.

Hall, Carolyn. El café y el desarrollo histórico-geográfico de Costa Rica. San José: Editorial Costa Rica y Universidad Nacional, 1976.

Herrera, Isabel. Monseñor Thiel en Costa Rica: visitas pastorales 1880-1901. Cartago: Ediciones Instituto Tecnológico de Costa Rica, 2009.

León, Jorge. Historia económica de Costa Rica en el siglo XX: crecimiento de políticas económicas. San José: Editorial de la Universidad de Costa Rica, 2014.

Menozzi, Daniele. Sacro Cuore. Un culto tra devozione interiore e restaurazione cristiana della societa. Roma: Editrice Viella, 2001.

Mora, Arnoldo. Las fuentes del cristianismo social en Costa Rica. San José: Departamento Ecuménico de Investigaciones (DEI), 1989.

Moreno V., Fernando. Iglesia, politica y sociedad. Santiago: Ediciones Universidad Católica de Chile, 1988.

Obregón, Clotilde (ed.). Las constituciones de Costa Rica, tomo IV. San José: Editorial Universidad de Costa Rica, 2007.

Picado, Miguel. La Iglesia costarricense entre Dios y el César. San José: Departamento Ecuménico de Investigaciones (DEI), 1989. 
La carta pastoral "Justo Salario": el intento de Mons. Thiel por iniciar con la Doctrina...

Picado, Miguel. La Palabra Social de los obispos costarricenses. Selección de documento de la Iglesia católica costarricense 1893-1981. San José: Departamento Ecuménico de Investigaciones (DEI), 1982.

Rusconi, Roberto. Santo Padre. La santità del papa da san Pietro a Giovanni Paolo II. Roma: Editrice Viella, 2010.

Sandí Morales, José Aurelio. Estado e Iglesia católica en Costa Rica 1850-1920: en los procesos de control del espacio geográfico y la creación de un modelo de costarricense. Heredia: Publicaciones UNA-SEBILA, 2012.

\section{Capítulos de libro}

De la Cruz, Vladimir. "Pobreza y lucha social en Costa Rica, 1870-1930”. Pobreza e Historia en Costa Rica. Determinantes estructurales y representaciones sociales del siglo XVII a 1950. Ed. Ronny Viales. San José: Editorial de la Universidad de Costa Rica, 2005.

Picciaredda, Stefano. "Protestanti e socialista alla prova dell'enciclica". Il mondo di Leone XIII. L'incontro della Chiesa con il XX secolo. Stefano Picciaredda e Vittorio V. Alberti. Roma: Edizioni liberal, 2006.

Thiel Hoffman, Bernardo. "Trigésima Carta Pastoral: Sobre el justo salario de los jornaleros y artesanos, y otros puntos de actualidad que se relacionan con la situación de los destituidos de bienes de fortuna. Del 5 de septiembre de 1891". La Palabra Social de los obispos costarricenses. Comp. Miguel Picado. San José: CECOR, 2007.

Viales, Ronny. "El régimen liberal de bienestar y la institucionalización de la pobreza en Costa Rica 1870-1930". Pobreza e Historia en Costa Rica. Determinantes estructurales y representaciones sociales del siglo XVII a 1950. Ed. Ronny Viales. San José: Editorial de la Universidad de Costa Rica, 2005.

\section{Artículos de revistas}

Menozzi, Daniele. "Regalità sociale de Cristo e secolarizzazione. Alle origini della Quasprimas”. Cristianesimo nella Storia 16 (1995): 79-113.

Menozzi, Daniele. "Un patrono per la Chiesa minacciata dalla Rivoluzione. Nuovi significati del culto di San Giuseppe tra Otto e Novecento". Rivista di Storia del Cristianesimo, año I, I (2005): 39-67.

Molina Jiménez, Iván. "El 89 de Costa Rica: otra interpretación del levantamiento del 7 de noviembre". Revista de Historia de Costa Rica. 20 (1989): 175-192. 
Montero, Andrea. "De grano de oro a grano de cobre: Los efectos de la primera crisis de sobreproducción en la Industria cafetalera costarricense (1896-1910)". Revista de Historia. 63-64 (2011): 101-117.

Rodríguez Sancho, Javier. "El Estado en Costa Rica, la iniciativa pública y privada frente al problema de la pobreza urbana. San José (1890-1930)". Anuario de Estudios Centroamericanos 1-2 (2000): 57-77.

Rusconi, Roberto. "Devozioni per il Pontefice e culto per il Papato al tempo di Pio IX e di Leone XIII nelle pagine di 'La Civiltà Cattolica”". Rivista di Storia del Cristianesimo, año II, I (2005): 9-37.

Salas, José Antonio. "La privatización de los baldíos nacionales en Costa Rica durante el siglo XIX: Legislación y procedimientos utilizados para su adjudicación”. Revista de Historia. 15 (1987): 63-118.

Sandí Morales, José Aurelio. "Las leyes anticlericales de 1884 en Costa Rica; una relectura desde otra perspectiva," SIWO. 3 (2010): 59-100.

Sandí Morales, José Aurelio. “Costa Rica en la geopolítica de la Santa Sede. La representación papal en Centroamérica entre 1908-1936”. Revista Espiga 15.32, (2016): 81-102.

\section{Tesis, ponencias, documentos y otros Inéditos}

Barrantes, Luis Osvaldo y otros. "Política social, beneficencia y abandono de niños en Costa Rica (1890-1930). Tesis de Licenciatura en Historia, Universidad de Costa Rica, 1995.

Sánchez, Esteban. "La participación político-partidista de la Iglesia: El Partido Unión Católica y sus estrategias de movilización política en el marco del conflicto entre la Iglesia católica y el Estado liberal en Costa Rica (1889-1898)". Tesis de Maestría, Universidad de Costa Rica, 2013.

Sandí Morales, José Aurelio. "La Santa Sede in Costa Rica 1870-1936. Il rapporto politico-religioso e diplomatico tra il governo del Costa Rica, la gerarchia cattolica del Paese e la Santa Sede nel periodo liberale costaricano". Tesi di dottorato, Scuola Normale Superiore, 2017.

Solano Muñoz, Edgar. "Iglesia, sociedad y relaciones de poder en Costa Rica 1881-1894". Tesis de Licenciatura en Historia, Universidad Nacional de Costa Rica. 1993.

\section{Publicaciones en Internet}

http://w2.vatican.va/content/leo-xiii/es/encyclicals/documents/hf_1-xiii_ enc_1505189) (San 1_rerum-novarum.html (2017)

www.binasss.sa.cr/revistas/hospitales/art72.pdf (2017) 